\title{
Ethnologies
}

\section{Booze: A Distilled History. By Craig Heron. (Toronto: Between the Lines, 2003. Pp. ix+497, ISBN 1-896357-83-0, plbk.)}

\section{Julie M.-A. LeBlanc}

Volume 26, numéro 2, 2004

Québec - Ethnologie du proche

Québec - Ethnology At Home

URI : https://id.erudit.org/iderudit/013757ar

DOI : https://doi.org/10.7202/013757ar

Aller au sommaire du numéro

\section{Éditeur(s)}

Association Canadienne d'Ethnologie et de Folklore

ISSN

1481-5974 (imprimé)

1708-0401 (numérique)

Découvrir la revue

Citer ce compte rendu

LeBlanc, J. M. (2004). Compte rendu de [Booze: A Distilled History. By Craig Heron. (Toronto: Between the Lines, 2003. Pp. ix+497, ISBN 1-896357-83-0, pbk.)]. Ethnologies, 26(2), 318-320. https://doi.org/10.7202/013757ar d'utilisation que vous pouvez consulter en ligne.

https://apropos.erudit.org/fr/usagers/politique-dutilisation/ 
Booze: A Distilled History. By Craig Heron. (Toronto: Between the Lines, 2003. Pp. ix+497, ISBN 1-896357-83-0, pbk.)

Less than two hundred years ago a culture surrounding a common product developed in North America, opening windows into communities and worlds which would have otherwise not been discovered. The product stirred controversies, curing ailments, leering some to addiction and others to enjoyable socialization. This product is alcohol, or "booze", as it is popularly termed and referenced by Craig Heron in his book Booze: A Distilled History. Heron, a scholar in Canadian history and labour studies, writes this book foremost as a historian, discussing social behaviours, intolerance, and acceptance of alcohol throughout Canada's history. Issues of class, gender, race, and age are discussed in the eleven chapters relating the physical effects of alcohol and its social implications in various cultural milieus of Canada and the United States. The book focuses primarily on Canada and offers a particular analysis on legislative, political and social regulations of alcohol. Although Heron briefly mentions alcohol-related activities in Canada prior to the nineteenth century, the author's particular era of interest is evidently alcohol's controversial period from the 1800 s onwards. The particular point in history where temperance movements occurred, that is at the turn of the 1820s, motivated Heron to describe decades-long battles between "drys" and "wets" in various regions of Canada. These battles, momentarily shifting from one political angle to the next, and reissued in later alcohol-related campaigns, are fought in various instances by different groups of people serving different purposes but with strong opinions in favour or against alcohol. Heron illustrates the strength of character found in the two opposing groups portraying the people and events and their relationship with alcohol. Throughout the book, Heron is aware of textual problems associated with the remains of these people and events, and expresses his concern while discussing drinking practices and perceptions of alcohol in the various periods of Canadian history. With these concerns, the author states that the most problematic of events pointing to alcohol relates to the bootlegging tradition which endured during prohibition. Heron even states that prohibition was a complete failure; but given the opaque, undocumented business practices of providing alcoholic drinks, it is not easy to determine the actual extent of that failure (264). The author compensates with some found facts on the effects of prohibition 
in a Canadian setting, recorded through political propaganda, remaining surveys and polls, and advertisements.

Booze: A Distilled History mainly addresses historians, sociologists and Canadiana researchers, but can benefit folklorists working on social behavioural patterns associated to drinking in Canada. Heron's arguments may be used as a prognosis on drinking societies by using historical facts as a template for reoccurring expressive discourses which may change in form but resonate similar concerns in future interactions. When Heron concluded by stating, "we have privatized this vice and now seem to have a simple message for drinkers: enjoy your booze, but please try to keep quiet about it" (388), he also summed the perception of alcohol throughout Canadian history as both hypocritical and relativistic. Propaganda from "wet" and "dry" campaigns have helped to learn more about drinking issues in Canada and have depicted a part of drinking practices that were condemned while illustrating the genres of people involved in drinking communities, as well as groups preaching against alcohol for its negative economical and emotional strain on the family nucleus and inefficient consequence to the nation's practical growth. Sobriety and resistance movements occurred after the realization of the possible dangers of alcohol abuse. Heron includes both urban and rural environments as his geographical canvas to discuss the movements and those involved in condemning and promoting alcohol. The industrialization of alcohol in Canada and the growing need for quality control and corporate responsibilities associated with marketing a consistent product is also discussed.

Heron illustrates how gender issues eventually dilute themselves in the "booze" industry by moving away from the predominantly masculinised consumption of alcohol in so-called dingy locations to the recent adoption of wine bars and bistros who serve alcohol to discriminating palates. Women were rarely associated with drinking practices and venues unless they were considered without morals in the early periods of alcohol controversy and eventually appeared in the late twentieth century involved in alcohol preparation, public serving, and consumption. There were many political controversies surrounding alcohol as Heron notes; plebiscites either promoting or prohibiting alcohol reccurred repeatedly in various regions of Canada and each province had its own approaches to dealing with the issue. Even with 
prohibition, alcohol still circulated because of smuggling-moguls, some of whom would become established entrepreneurs of well-known beverage dynasties in the country, such as the Bronfmans. This book illustrates the figures who were involved with the temperance movements, during prohibition, and in the promotion of alcohol in Canada over the centuries. In short, Canada's highly active underground period of alcohol smuggling lead the way towards a "drinking consciousness" which benefited and ruined some Canadians in business and personal affairs.

Booze: A Distilled History is a useful contribution to the history of Canadian alcohol activities and also depicts shared traits amongst particular groups of people involved in its creation, distribution, and consumption. Readers may benefit from each chapter individually as it is organized in themes relating events chronologically within the sections. Theoretical analyses are only apparent when dealing directly with historical notions in the book such as gender, nationalism, communalism, and Marxism. The book could be used as an accompanying tool for discussing particular aspects of folklore such as the material culture surrounding taverns, pubs, nineteenth-century saloons, and also bottles or labels; political campaigning or advertisement paraphernalia; industrial vs. homemade alcoholic beverages and other drinking traditions. The author successfully weaves his arguments surrounding "booze" to glean the many traits associated with the product from a historical perspective. Heron mentions that there are loopholes in the research which could offer interesting venues for future studies, but also notes that there are limits considering the lack of information in certain statistical fields and national surveys of varying periods. Overall, Heron manages with ease the question of alcohol in society as a motivation for social gatherings and as a controversial subject. Booze: A Distilled History is captivating with its archival and historical details and is valuable for any scholar interested in political movements, propaganda affairs, community gatherings, and personal histories of influential business persons and industrialism tied to one particular product.

Julie M.-A. LeBlanc

Memorial University of Newfoundland

St. John's 